\title{
Mutagenicity, genotoxicity, and scavenging activities of extracts from the soft coral Chromonephthea braziliensis: a possibility of new bioactive compounds
}

\author{
R.M. Carpes ${ }^{1}$, B.G. Fleury ${ }^{2}$, B.G. Lages ${ }^{2}$, A.C. Pinto ${ }^{3}$, C.A.F. Aiub ${ }^{4}$ and \\ I. Felzenszwalb ${ }^{1}$
}

${ }^{1}$ Laboratório de Mutagênese Ambiental, Departamento de Biofísica e Biometria, Instituto de Biologia Roberto Alcântara Gomes, Universidade do Estado do Rio de Janeiro, Rio de Janeiro, RJ, Brasil ${ }^{2}$ Departamento de Ecologia, Instituto de Biologia Roberto Alcântara Gomes, Universidade do Estado do Rio de Janeiro, Rio de Janeiro, RJ, Brasil ${ }^{3}$ Departamento de Química Orgânica, Instituto de Química, Universidade Federal do Rio de Janeiro, Rio de Janeiro, RJ, Brasil ${ }^{4}$ Laboratório de Genotoxicidade, Departamento de Genética e Biologia Molecular, Instituto Biomédico, Universidade Federal do Estado do Rio de Janeiro, Rio de Janeiro, RJ, Brasil

Corresponding author: I. Felzenszwalb E-mail: uerj.felzen@gmail.com

Genet. Mol. Res. 12 (3): 3575-3587 (2013)

Received March 17, 2013

Accepted August 7, 2013

Published September 13, 2013

DOI http://dx.doi.org/10.4238/2013.September.13.2

\begin{abstract}
Coral reefs are diverse ecosystems that have a high density of biodiversity leading to intense competition among species. These species may produce unknown substances, many with pharmacological value. Chromonephthea braziliensis is an invasive soft coral from the Indo-Pacific Ocean that is possibly transported by oil platforms and whose presence can be a threat to a region's biodiversity. This species produces secondary metabolites that are responsible for inducing damage to the local ecosystem. In the present study, extracts
\end{abstract}


were prepared from dried colonies of $C$. braziliensis (solvents: hexane, dichloromethane, ethyl acetate, and methanol). We evaluated their mutagenicity using the Salmonella reverse mutation assay (TA97, TA98, TA100, and TA102 strains), their genotoxicity using the DNA breakage analysis and micronucleus assay, and scavenging activity using the 1,1-diphenyl-2-picrylhydrazyl-free radical assay. Cytotoxicity and mutagenicity were not observed for any of the extracts. Genotoxicity was observed for the dichloromethane, ethyl acetate, and methanol extracts at high concentrations, but no DNA damage was observed in the micronucleus assay. Scavenging activity was not detected.

Key words: Chromonephthea braziliensis; Mutagenicity; Toxicity; Secondary metabolites

\section{INTRODUCTION}

The marine environment contains an as yet untapped wealth of useful products for the treatment of infectious diseases (Donia and Hamann, 2003). It can be argued that pharmacological research involving marine organisms is intrinsically slower and has disadvantages compared to programs based on synthesis, but the number and quality of leads generated more than justify research in marine pharmacology (Faulkner, 2000).

A growing number of discoveries have been made of marine compounds with biological activity or properties of great interest. In the marine environment, sponges are responsible for the highest proportion of these findings (Sipkema et al., 2005; Stankevicins et al., 2008). However, coral reefs are the most diverse ecosystems in the sea and have the highest density of biodiversity globally. High species diversity gives rise to intense competition amongst species, with the surviving organisms having the capability to construct exotic defensive and offensive chemicals, many with pharmacological value (Adey, 2000).

Soft corals are very common in the Indo-Pacific reefs and in certain areas of the Great Barrier Reef. Although common species of corals are potentially rich in proteins, carbohydrates, and lipids, they are subject to relatively low levels of predation since they produce large amounts of protective secondary metabolites (Coll, 1992; Sammarco and Coll, 1992). Studies of the chemical defenses of corals have been limited to species of the Anthozoa class, comprising the Gorgonacea and Alcyonacea orders (Octocorallia subclass) (Pawlik, 1993).

Terpenes and their derivatives (terpenoids) comprise the prevailing class of substances in Octocorallia, and therefore in Alcyonacea. Studies of these substances have identified functional properties of great interest. For example, compounds like limonene, perillyl alcohol, and carvone that can act in the prevention of degenerative diseases, among others that are being studied as chemotherapeutic agents (Maróstica Júnior, 2008). Research in other properties, such as natural insecticides and antimicrobials, are examples of the importance that these chemicals have received (Maróstica Júnior, 2008).

The soft coral Chromonephthea braziliensis (Alcyonacea, Nephtheidae; Ofwegen, 2005) was first recorded in Arraial do Cabo, southeastern Brazil (Ferreira, 2003). Studies have shown that the presence of $C$. braziliensis in Brazilian waters can be a real threat to the region's biodiversity, especially endemic species of corals, such as the gorgonian Phyllogorgia 
dilatata (Lages et al., 2006). This exotic coral produces secondary metabolites that confer it with beneficial action against native species, contributing to its defense against fish predators and increasing its success in competition for space (Lages et al., 2006; Fleury et al., 2008; Oliveira and Medeiros, 2008).

This study aimed to carry out qualitative and quantitative cytotoxic, mutagenic, genotoxic, and scavenging evaluations of hexane (n-Hex), dichloromethane (DCM), ethyl acetate (EtOAc), and methanol $(\mathrm{MeOH})$ extracts from C. braziliensis. The motivation of this analysis is the development of future drugs for general chemotherapy based on the structure of bioactive compounds.

\section{MATERIAL AND METHODS}

\section{Collection and extraction}

The $C$. braziliensis colonies were collected by scuba diving to $8 \mathrm{~m}$ depth in May 2004 in a marine reserve in the Arraial do Cabo region of Rio de Janeiro State $\left(23^{\circ} 44^{\prime} \mathrm{S}-42^{\circ} 02^{\prime} \mathrm{W}\right)$, southeastern Brazil. The samples generated a total mass of $286 \mathrm{~g}$ freeze-dried coral and were extracted in 3 consecutive times, then sonicated with each solvent sequentially. The results are shown in Table 1.

\begin{tabular}{ll} 
Table 1. Yield from the extracts. \\
\hline Chromonephthea braziliensis \\
\hline Freeze-dried coral & $286 \mathrm{~g}$ \\
Hexane extract (n-Hex) & $9.20 \mathrm{~g}$ \\
Dichloromethane extract (DCM) & $3.00 \mathrm{~g}$ \\
Ethyl acetate extract (EtOAc) & $0.387 \mathrm{~g}$ \\
Methanol extract (MeOH) & $2.93 \mathrm{~g}$ \\
\hline
\end{tabular}

\section{Bacterial strains}

The features of Salmonella typhimurium strains TA97, TA98, TA100, and TA102 (from our stock) are shown in Table 2.

Table 2. Genotypic and phenotypic characteristics of standard strains derived from Salmonella typhimurium LT2.

\begin{tabular}{|c|c|c|c|c|c|}
\hline Strain & His mutation & Plasmids & Other mutations & \multicolumn{2}{|c|}{ Type of mutation detected } \\
\hline TA97 & hisD6610; hisO1242 & pKM101 & rfa $\Delta($ uvrB chl bio $)$ & Frameshift & G:C pair addition \\
\hline TA98 & hisD3052 & pKM101 & rfa $\Delta($ uvrB chl bio $)$ & Frameshift & $\mathrm{G}: \mathrm{C}$ pair deletion \\
\hline TA100 & his $G 46$ & pKM101 & rfa $\Delta($ (uvrB chl bio $)$ & Substitution & $\mathrm{G}: \mathrm{C}$ to $\mathrm{A}: \mathrm{T}$ \\
\hline TA102 & pAQ1(hisG428) & pKM101,pAQ1 & $r f a$ & Substitution & A:T to $\mathrm{G}: \mathrm{C}$ \\
\hline
\end{tabular}

\section{Bacterial reverse mutation test}

The test tube contained a mixture of $100 \mu \mathrm{L}$ of 1 of the 4 extracts of $C$. braziliensis concentrations $(0.5,5,10$, and $20 \mu \mathrm{g} /$ plate), $500 \mu \mathrm{L}$ sodium phosphate buffer $(27.6 \mathrm{~g} / \mathrm{L}$ $\mathrm{NaH}_{2} \mathrm{PO}_{4} \cdot \mathrm{H}_{2} \mathrm{O}$ and $\left.28.4 \mathrm{~g} / \mathrm{L} \mathrm{Na}_{2} \mathrm{HPO}_{4} ; 0.2 \mathrm{M}, \mathrm{pH} 7.4\right)$ and $100 \mu \mathrm{L}$ bacterial suspension $(2 \mathrm{x}$ 
$10^{9}$ cells $\left./ \mathrm{mL}\right)$. Then, $2 \mathrm{~mL}$ top agar $(7 \mathrm{~g} / \mathrm{L}$ agar; $5 \mathrm{~g} / \mathrm{L} \mathrm{NaCl} ; 0.0105 \mathrm{~g} / \mathrm{L}$ L-histidine; $0.0122 \mathrm{~g} / \mathrm{L}$ biotin, $\mathrm{pH} 7.4,45^{\circ} \mathrm{C}$ ) was added to the test tube and the final mixture was poured onto a Petri dish with minimal agar $\left[15 \mathrm{~g} / \mathrm{L}\right.$ agar, Vogel-Bonner E medium $10 \mathrm{X}\left(10 \mathrm{~g} / \mathrm{L} \mathrm{MgSO}_{4} \cdot 7 \mathrm{H}_{2} \mathrm{O}\right.$; $\left.100 \mathrm{~g} / \mathrm{L} \mathrm{C}_{6} \mathrm{H}_{8} \mathrm{O}_{7} \cdot \mathrm{H}_{2} \mathrm{O} ; 500 \mathrm{~g} / \mathrm{L} \mathrm{K}_{2} \mathrm{HPO}_{4} ; 175 \mathrm{~g} / \mathrm{L} \mathrm{Na}\left(\mathrm{NH}_{4}\right) \mathrm{HPO}_{4} \cdot 4 \mathrm{H}_{2} \mathrm{O}\right)$ ] containing $20 \mathrm{~g} / \mathrm{L}$ glucose. This final mixture was incubated at $37^{\circ} \mathrm{C}$ for $72 \mathrm{~h}$, and the $\mathrm{His}^{+}$revertant colonies were counted.

The positive controls for assays in the absence of S9 mix were as follows: 4-nitroquinoline 1-oxide (CAS: 56-57-5) at $1.0 \mu \mathrm{g} / \mathrm{plate}$ for TA97; 4-NQO at $0.5 \mu \mathrm{g} / \mathrm{plate}$ for TA98; sodium azide (CAS: 26628-22-8) at $0.5 \mu \mathrm{g} / \mathrm{plate}$ for TA100; and mitomycin C (CAS: 50-07-7) at $0.5 \mu \mathrm{g} / \mathrm{plate}$ for TA102. All the chemicals used were from Sigma (USA).

The substance or sample was considered positive for mutagenicity when: a) the number of revertant colonies in the test assay was at least twice the number of spontaneous revertants (mutagenicity induction $\geq 2$ ), calculated as the number of $\mathrm{His}^{+}$induced in the sample divided by the number of spontaneous $\mathrm{His}^{+}$in the negative control; b) a significant response for analysis of variance (ANOVA, $\mathrm{P} \leq 0.05$ ) and the Student $t$-test was found; $\mathrm{c}$ ) a reproducible positive dose-response curve $(\mathrm{P} \leq 0.01)$ was present. All experiments were done in triplicate (Maron and Ames, 1983).

\section{Survival experiments}

Quantitative evaluations were made to determine the cytotoxic effects of the concentrations of the 4 extracts of $C$. braziliensis. In the assay, $10 \mu \mathrm{L}$ bacterial suspension treated as described for the Ames test was diluted with a saline solution $(9 \mathrm{~g} / \mathrm{L} \mathrm{NaCl})$. Then, $100 \mu \mathrm{L}$ mix solution was put on a Petri dish with solid LB medium. The total dilution was $10^{-7}$-fold. These dishes were incubated at $37^{\circ} \mathrm{C}$ for $24 \mathrm{~h}$. The colonies were counted and a percentage calculation was made relative to the negative control.

\section{DNA breakage analysis}

The plasmid pUC18 was extracted from Escherichia coli DH5 $\alpha$ strain using a kit for plasmid DNA extraction (Miniprep Kit for plasmid) from Axygen Biosciences (USA). Electrophoresis was performed on $0.8 \%$ agarose gel in order to separate different structural conformations of pUC18: form I, supercoiled native conformation; form II, open circle resulting from single-strand breaks; and form III, linear resulting from double-strand breaks. The electrophoresis assay was also used to verify if there was a delay in DNA migration. Aliquots $(5 \mu \mathrm{L})$ of each extract at different concentrations $(28.6,50,100$, and $250 \mu \mathrm{g} / \mathrm{mL})$ with the plasmid $(0.4 \mu \mathrm{g})$ were incubated for $10 \mathrm{~min}$ at $37^{\circ} \mathrm{C}$ and submitted to electrophoretic migration for 15 min $\left(\mathrm{E}-\mathrm{Gel}^{\circledR}{ }^{\circledR} \mathrm{BBase}^{\mathrm{TM}}\right.$ Power System) and visualized by ultraviolet transilluminator $\left(\mathrm{E}_{-\mathrm{Gel}}{ }^{\circledR}\right.$ Safe Imager ${ }^{\mathrm{TM}}$ Real-Time Transilluminator) both from Invitrogen (USA). The images were digitalized in a photo documentation system using the ImageJ $1.36 \mathrm{~b}$ software to perform the quantification of the bands. The quantitative analysis was done only once.

The assay included a positive control using stannous chloride $\left(\mathrm{SnCl}_{2}, \mathrm{CAS}\right.$ : 777299-8) at 100 and $200 \mu \mathrm{g} / \mathrm{mL}$ concentrations (Sigma) (Gomes et al., 1996; Felzenszwalb et al., 1998). 


\section{Micronuclei in macrophages}

The RAW264.7 macrophage strain was used from a confluence culture. Eagle's minimum essential medium ( $950 \mu \mathrm{L}$ MEM; $1.8 \mathrm{mM} \mathrm{Ca}^{2+}, \mathrm{pH} 7.6$; Gibco, USA) was supplemented with $1.76 \mathrm{~g} / \mathrm{L} \mathrm{NaHCO}_{3}, 0.88 \mathrm{~g} / \mathrm{L}$ pyruvate, $21.6 \mathrm{mg} / \mathrm{L}$ aspartic acid, and $16.8 \mathrm{mg} / \mathrm{L}$ L-serine, with $10 \%$ fetal bovine serum (FBS), both at $37^{\circ} \mathrm{C}$. Next, $50 \mu \mathrm{L} 2$ x $10^{5}$ cells $/ \mathrm{mL}$ suspended cells was added to 24 wells of a microtiter plate containing a coverslip that had been pre-treated with $0.1 \mathrm{M}$ nitric acid for $15 \mathrm{~min}$. This suspension was maintained in Eagle's MEM Ca ${ }^{2+} 1.8 \mathrm{mM}$, containing $10 \% \mathrm{FBS}, 100 \mathrm{mg} / \mathrm{L}$ streptomycin, and $70 \mathrm{mg} / \mathrm{L}$ penicillin. The plates were placed in an incubator with an atmosphere of $5 \%$ $\mathrm{CO}_{2}$ for $24 \mathrm{~h}$.

For cell treatment, $100 \mu \mathrm{L}$ of the 4 concentrations (20,200, 350, and $500 \mu \mathrm{g} / \mathrm{mL}$ ) of the 4 extracts of $C$. braziliensis (n-Hex, DCM, EtOAc, and MeOH) was added, equivalent to $10 \%$ of total volume, and the plates were incubated for $24 \mathrm{~h}$. After the incubation period, the medium was removed and the cells were rinsed with $1 \mathrm{~mL}$ Eagle's MEM. One milliliter medium supplemented with FBS (10\%) was added and the cells were re-incubated for an additional $24 \mathrm{~h}$ in an incubator with an atmosphere of $5 \% \mathrm{CO}_{2}$. The positive control was $\mathrm{N}$-methyl-N-nitro-N-nitrosoguanidine at a concentration of $0.5 \mathrm{mM}$.

The Eagle's MEM was replaced with cold fixative solution methanol-glacial acetic acid (3:1) for $15 \mathrm{~min}$. The fixed cells were rinsed with McIlvaine buffer (MI buffer: 21.01 $\mathrm{g} / \mathrm{L}$ citric acid and $35.60 \mathrm{~g} / \mathrm{L} \mathrm{Na}_{2} \mathrm{HPO}_{4}, \mathrm{pH} 7.5$ ) for 2 min and dried at room temperature. The fixed cells were stained with $0.2 \mu \mathrm{g} / \mathrm{mL}$ 4'-6-diamidino-2-phenylindole dissolved in MI buffer for $40 \mathrm{~min}$. Cells were washed with MI buffer for 2 min followed by distilled water and dried again at room temperature. To determine the mitotic index, the number of cells with micronuclei and the percentages of necrosis and apoptosis (1000 cells per concentration, triplicate) were analyzed in a fluorescence microscope (Reichert Univar) with an excitation wavelength of $350 \mathrm{~nm}$ (Eckl et al., 1987).

\section{Protein quantification}

We evaluated the protein composition using Qubit ${ }^{\mathrm{TM}}$ Protein Assay Kit (Q33211) as recommended by Invitrogen. Three different considerations can be made regarding the protein concentration: a) the increased protein concentration was related to the decreased bioavailability of secondary metabolites in the form of free secondary metabolites; b) the decrease in the protein concentration could be due to sequential extraction; and c) the proteins present in the extracts could act as scavengers.

\section{DPPH-free radical scavenging activity assay}

An aliquot of $1.0 \mathrm{~mL} 0.25 \mathrm{mM}$ DPPH solution in ethanol and $1.0 \mathrm{~mL}$ of 1 of the 4 concentrations $(0.001 ; 0.01 ; 0.1 ; 1.0 \mathrm{mg} / \mathrm{mL})$ for each extract were mixed. The mixture was vigorously shaken and allowed to reach a steady state at room temperature for $30 \mathrm{~min}$. Decolorization of DPPH was determined by measuring spectrophotometric absorbance at 517 $\mathrm{nm}$. The capability to scavenge DPPH radicals was calculated by the following equation: scavenging rate $=[1$ - (absorbance of the sample at $517 \mathrm{~nm} /$ absorbance of the control at 
$517 \mathrm{~nm})] \times 100 \%$. The same procedure was done using proteinase $\mathrm{K}$ in order to isolate substances from proteins present in the extracts. The samples were incubated with $250 \mu \mathrm{g} / \mathrm{mL}$ proteinase $\mathrm{K}$ for $60 \mathrm{~min}$ at $50^{\circ} \mathrm{C}$. One milliliter $0.25 \mathrm{mM}$ DPPH was added to the final mix and the decolorization of DPPH was measured at $517 \mathrm{~nm}$ after $30 \mathrm{~min}$ at room temperature (Amarowicz, 2000).

\section{Statistical analysis}

For the S. typhimurium reverse mutation assay, mutagenicity was identified when the mutagenic index was at least twice the spontaneous rate (in the negative control). Survival rates of $70 \%$ less than the negative control indicated cytotoxicity. Significant statistical differences between negative and tested concentrations under the same experimental conditions were verified using the Student $t$-test $(\mathrm{P}<0.05)$ (Stankevicins et al., 2008).

The data for micronuclei were analyzed using a one-way ANOVA and the TukeyKramer multiple comparison test using the GraphPad Instat ${ }^{\circledR}$ software, version 3.01 (GraphPad Software, Inc., USA). Results were considered to be statistically significant at $\mathrm{P}<0.05$.

\section{RESULTS AND DISCUSSION}

\section{Quantitative survival and bacterial reverse mutation assays}

We used the 4 bacterial strains in the mutagenic and cytotoxic assays due to their high sensitivity to various compounds. TA97 presents a mutation which, when altered by base pair deletion (frameshift), generates resistance to mutagens. This mutation allows growth on minimal medium. TA98 has a spontaneous mutation that decreases its level of nitroredutase activity. TA100 detects agents that induce methylation and cause the replacement of base pairs. The replacement of A:T by G:C triggers the start of the biosynthesis of histidine, restoring the wild phenotype. TA98 and TA100 are used to study the metabolism and mutagenicity of carcinogens, even though they are nitroredutase deficient. TA102 has an auxotrophic nature; it contains an A:T base pair at the critical site for reversion (the other strains have G:C base pairs). It detects a variety of oxidative mutagens and crosslink agents that preferentially attack A:T base pairs (Levin et al., 1982; Maron and Ames, 1983). However, no positive response was observed for mutagenic and cytotoxic assays.

Tables 3 and 4 present the analysis of the mutagenic and/or cytotoxic response for n-Hex, DCM, EtOAc, and MeOH extracts of C. braziliensis.

The n-Hex extract did not show a mutagenic response, but a toxicity signal was observed for TA102 at the highest concentration by a decrease in the percentage of survival. In the DCM extract, the mutagenic and cytotoxic effects were negative, but the survival rate decreased in a dose-dependent fashion when the extract was in contact with the TA97 strain.

The EtOAc extract did not induce cytotoxic or mutagenic effects, although the survival rate did decrease when the extract was in contact with the TA97 and TA100 strains. The $\mathrm{MeOH}$ extract followed the patterns of the DCM and EtOAc extracts, without mutagenic or cytotoxic effects. 
Table 3. Mutagenicity and cytotoxicity for hexane and dichloromethane extracts of Chromonephthea braziliensis.

\begin{tabular}{|c|c|c|c|c|c|c|c|}
\hline \multirow[t]{2}{*}{ Strain } & \multirow[t]{2}{*}{ C. braziliensis ( $\mu \mathrm{g} / \mathrm{plate})$} & \multicolumn{3}{|c|}{ Hexane extract } & \multicolumn{3}{|c|}{ Dichloromethane extract } \\
\hline & & M.I. ${ }^{\mathrm{a}}$ & $\mathrm{His}^{+} \pm \mathrm{SD}^{\mathrm{b}}$ & $\overline{\% \text { Survival }^{c}}$ & M.I. ${ }^{a}$ & $\mathrm{His}^{+} \pm \mathrm{SD}^{\mathrm{b}}$ & $\%$ Survival $^{c}$ \\
\hline \multirow[t]{6}{*}{ TA97 } & DMSO & 1.0 & $132 \pm 5$ & 100 & 1.0 & $176 \pm 49$ & 100 \\
\hline & 0.5 & 0.7 & $94 \pm 9^{*}$ & 100 & 0.9 & $162 \pm 52$ & 95 \\
\hline & 5 & 0.8 & $100 \pm 11 *$ & 100 & 0.9 & $162 \pm 34$ & 90 \\
\hline & 10 & 0.8 & $110 \pm 16$ & 100 & 1.0 & $170 \pm 38$ & 80 \\
\hline & 20 & 1.0 & $131 \pm 13$ & 100 & 0.9 & $165 \pm 12$ & 80 \\
\hline & 4-NQO $(1.0 \mu \mathrm{g} / \mathrm{plate})$ & 2.8 & $368 \pm 27$ & & 5.3 & $934 \pm 361$ & \\
\hline \multirow[t]{6}{*}{ TA98 } & DMSO & 1.0 & $18 \pm 3$ & 100 & 1.0 & $28 \pm 4$ & 100 \\
\hline & 0.5 & 1.4 & $26 \pm 7$ & 100 & 1.1 & $29 \pm 8$ & 100 \\
\hline & 5 & 1.1 & $21 \pm 2$ & 100 & 1.0 & $28 \pm 6$ & 100 \\
\hline & 10 & 0.7 & $12 \pm 3$ & 87 & 1.1 & $30 \pm 2$ & 100 \\
\hline & 20 & 0.8 & $14 \pm 7$ & 100 & 1.0 & $28 \pm 7$ & 100 \\
\hline & 4-NQO $(0.5 \mu \mathrm{g} /$ plate $)$ & 10 & $183 \pm 0$ & & 35.9 & $993 \pm 272$ & \\
\hline \multirow[t]{6}{*}{ TA100 } & DMSO & 1.0 & $146 \pm 12$ & 100 & 1.0 & $246 \pm 16$ & 100 \\
\hline & 0.5 & 0.7 & $100 \pm 8^{*}$ & 89 & 1.0 & $248 \pm 25$ & 100 \\
\hline & 5 & 0.9 & $131 \pm 12$ & 86 & 1.1 & $262 \pm 21$ & 100 \\
\hline & 10 & 0.9 & $133 \pm 20$ & 96 & 1.1 & $263 \pm 34$ & 100 \\
\hline & 20 & 0.7 & $96 \pm 18^{*}$ & 88 & 0.9 & $227 \pm 18$ & 100 \\
\hline & SA $(0.5 \mu \mathrm{g} /$ plate $)$ & 5.1 & $751 \pm 61$ & & 11 & $2673 \pm 805$ & \\
\hline \multirow[t]{6}{*}{ TA102 } & DMSO & 1.0 & $229 \pm 43$ & 100 & 1.0 & $346 \pm 65$ & 100 \\
\hline & 0.5 & 0.7 & $170 \pm 36$ & 90 & 1.1 & $370 \pm 95$ & 100 \\
\hline & 5 & 1.0 & $220 \pm 19$ & 90 & 1.1 & $390 \pm 72$ & 100 \\
\hline & 10 & 0.9 & $216 \pm 99$ & 90 & 1.1 & $372 \pm 90$ & 100 \\
\hline & 20 & 1.0 & $230 \pm 162$ & 84 & 0.8 & $277 \pm 78$ & 100 \\
\hline & MitC $(0.5 \mu \mathrm{g} /$ plate $)$ & 4.3 & $989 \pm 95$ & & 3.0 & $1036 \pm 464$ & \\
\hline
\end{tabular}

${ }^{\mathrm{a}}$ Mutagenic index: No. of $\mathrm{His}^{+}$induced in the sample/number of spontaneous $\mathrm{His}^{+}$in the negative control (DMSO). ${ }^{\mathrm{b}} \mathrm{His}^{+} /$ plate: mean values of at least 3 replicate plates. 'Percent survival relative to the negative control: toxicity is considered when percent survival $<70 \%$ related to the control group. Positive controls are described in the Experimental section. Significant statistical differences between negative control and tested concentrations under the same experimental conditions are identified by an asterisk $(\mathrm{P}<0.05) .4-\mathrm{NQO}=\mathrm{DMSO}=$ dimethyl sulfoxide; 4-nitroquinoline 1-oxide; SA $=$ sodium azide; $\mathrm{Mit} \mathrm{C}=$ mitomycin $\mathrm{C}$.

\section{DNA breakage analysis}

The results shown in Figure 1 are for the highest concentrations of the extracts of $C$. braziliensis $(250 \mu \mathrm{g} / \mathrm{mL})$. No positive response was observed for the other concentrations (28.6, 50, and $100 \mu \mathrm{g} / \mathrm{mL}$; data not shown). These concentrations were used to compare with the mutagenic and cytotoxic assays at the highest concentration $(20 \mu \mathrm{g} / \mathrm{plate})$ and the genotoxic assay with eukaryotic cells (WHO, 2002).

Melatonin has a potent-free radical scavenger and antioxidant effect (Reiter et al., 1995). It can detoxify highly toxic hydroxyl radicals and peroxyl radicals in vitro (Reiter et al., 2001). In this way, melatonin exerts a protective effect under certain pathological conditions such as damage caused by drug toxicity in which a common feature is the existence of mitochondrial damage (Reiter et al., 1995; Karbownik and Reiter, 2000). One millimolar melatonin (N-acetyl-5-methoxytryptamine) was dissolved in $50 \mathrm{mM}$ sodium phosphate buffer, $\mathrm{pH} 7.4$, with 10\% methanol (Onuki et al., 2005). The reaction mixtures were incubated at $37^{\circ} \mathrm{C}$ for $2 \mathrm{~h}$. Melatonin was able to detoxify reactive oxygen species generated by DCM, EtOAc, and $\mathrm{MeOH}$ extracts avoiding the formation of 8-oxo-7,8-dihydro-2'-deoxyguanosine (8-oxo-dGuo) (Burkhardt et al., 2001) (Figure 2).

Cytotoxic effects of terpenes and terpenoids on different organelles, such as mitochondria, were already known. They generate chain reactions from the cell wall or the outer cell membrane and invade the whole cell, which affects activities such as membrane potential, ionic channels, and regulation of $\mathrm{pH}$ gradients, ultimately leading to cell death by apoptosis and necrosis (Bakkali et al., 2008). 
Table 4. Mutagenicity and cytotoxicity for ethyl acetate and methanol extracts of Chromonephthea braziliensis.

\begin{tabular}{|c|c|c|c|c|c|c|c|}
\hline \multirow[t]{2}{*}{ Strain } & \multirow[t]{2}{*}{ C. braziliensis ( $\mu \mathrm{g} / \mathrm{plate})$} & \multicolumn{3}{|c|}{ Ethyl acetate extract } & \multicolumn{3}{|c|}{ Methanol extract } \\
\hline & & M.I. ${ }^{a}$ & $\mathrm{His}^{+} \pm \mathrm{SD}^{\mathrm{b}}$ & $\%$ Survival $^{\mathrm{c}}$ & M.I. ${ }^{a}$ & $\mathrm{His}^{+} \pm \mathrm{SD}^{\mathrm{b}}$ & $\%$ Survival $^{c}$ \\
\hline \multirow[t]{6}{*}{ TA97 } & DMSO & 1.0 & $128 \pm 25$ & 100 & 1.0 & $112 \pm 30$ & 100 \\
\hline & 0.5 & 1.4 & $174 \pm 33$ & 95 & 1.1 & $128 \pm 8$ & 100 \\
\hline & 5 & 1.3 & $164 \pm 31$ & 95 & 0.8 & $91 \pm 5$ & 100 \\
\hline & 10 & 1.2 & $151 \pm 20$ & 90 & 0.9 & $99 \pm 6$ & 100 \\
\hline & 20 & 1.0 & $135 \pm 10$ & 80 & 1.1 & $126 \pm 40$ & 100 \\
\hline & 4-NQO $(1.0 \mu \mathrm{g} /$ plate $)$ & 6.6 & $853 \pm 188$ & & 8.7 & $974 \pm 108$ & \\
\hline \multirow[t]{6}{*}{ TA98 } & DMSO & 1.0 & $37 \pm 2$ & 100 & 1.0 & $24 \pm 1$ & 100 \\
\hline & 0.5 & 1.1 & $39 \pm 7$ & 100 & 1.0 & $23 \pm 5$ & 100 \\
\hline & 5 & 0.8 & $30 \pm 4$ & 100 & 1.1 & $26 \pm 4$ & 100 \\
\hline & 10 & 0.9 & $31 \pm 9$ & 100 & 0.7 & $17 \pm 3$ & 100 \\
\hline & 20 & 1.1 & $39 \pm 12$ & 100 & 0.9 & $20 \pm 2$ & 100 \\
\hline & 4-NQO $(0.5 \mu \mathrm{g} /$ plate $)$ & 9.9 & $362 \pm 42$ & & 20 & $479 \pm 97$ & \\
\hline \multirow[t]{6}{*}{ TA100 } & DMSO & 1.0 & $201 \pm 35$ & 100 & 1.0 & $195 \pm 7$ & 100 \\
\hline & 0.5 & 1.0 & $208 \pm 4$ & 100 & 0.8 & $160 \pm 3^{*}$ & 100 \\
\hline & 5 & 0.9 & $184 \pm 22$ & 95 & 0.9 & $182 \pm 12$ & 100 \\
\hline & 10 & 0.9 & $184 \pm 27$ & 90 & 1.0 & $193 \pm 5$ & 100 \\
\hline & 20 & 1.1 & $218 \pm 25$ & 90 & 1.0 & $186 \pm 18$ & 95 \\
\hline & $\mathrm{SA}(0.5 \mu \mathrm{g} /$ plate $)$ & 15 & $2929 \pm 478$ & & 14 & $2680 \pm 103$ & \\
\hline \multirow[t]{6}{*}{ TA102 } & DMSO & 1.0 & $329 \pm 27$ & 100 & 1.0 & $334 \pm 9$ & 100 \\
\hline & 0.5 & 1.1 & $361 \pm 19$ & 100 & 1.0 & $350 \pm 29$ & 100 \\
\hline & 5 & 0.7 & $229 \pm 93$ & 100 & 0.9 & $310 \pm 34$ & 100 \\
\hline & 10 & 0.8 & $265 \pm 6$ & 100 & 0.9 & $293 \pm 48$ & 100 \\
\hline & 20 & 0.9 & $295 \pm 6$ & 100 & 0.9 & $297 \pm 25$ & 100 \\
\hline & $\operatorname{MitC}(0.5 \mu \mathrm{g} /$ plate $)$ & 5.2 & $1703 \pm 120$ & & 3.2 & $1067 \pm 219$ & \\
\hline
\end{tabular}

a Mutagenic index: No. of $\mathrm{His}^{+}$induced in the sample/number of spontaneous $\mathrm{His}^{+}$in the negative control (DMSO). ${ }^{\mathrm{b}} \mathrm{His}^{+} /$plate: mean values of at least 3 replicate plates. ${ }^{\mathrm{c}}$ Percent survival relative to the negative control: toxicity is considered when percent survival $<70 \%$ related to the control group. Positive controls are described in the Experimental section. Significant statistical differences between negative control and tested concentrations under the same experimental conditions are identified by an asterisk $(\mathrm{P}<0.05)$. For abbreviations, see legend to Table 3 .

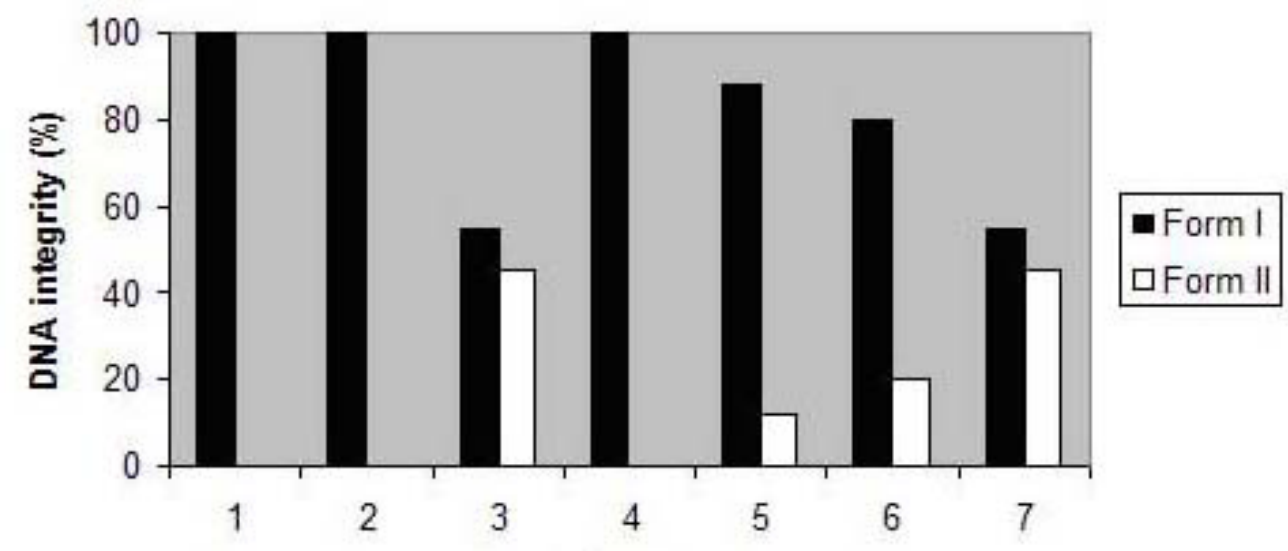

Figure 1. DNA breakage analysis using $0.8 \%$ agarose gel incubating $0.4 \mu \mathrm{g}$ pUC18 plasmid with each of the 4 extracts of Chromonephthea braziliensis. $1=\mathrm{H}_{2} \mathrm{O} ; 2=$ DMSO; $3=200 \mu \mathrm{g} / \mathrm{mL} \mathrm{SnCl}_{2} ; 4=250 \mu \mathrm{g} / \mathrm{mL}$ hexanic extract; $5=250 \mu \mathrm{g} / \mathrm{mL}$ dichloromethane extract; $6=250 \mu \mathrm{g} / \mathrm{mL}$ ethyl acetate extract; $7=250 \mu \mathrm{g} / \mathrm{mL}$ methanol extract. Form $\mathrm{I}=$ supercoiled native conformation; form II = open circle resulting from single-strand breaks. 


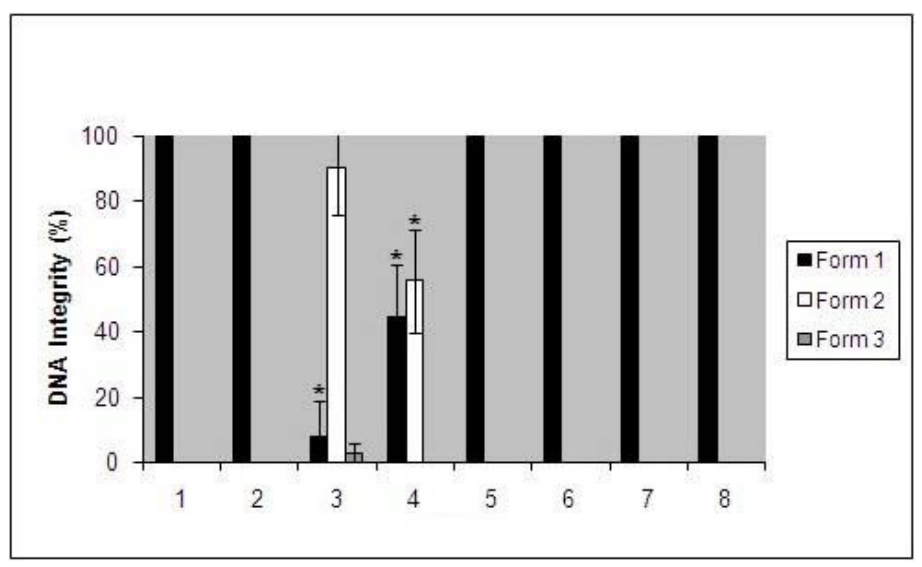

Figure 2. DNA breakage analysis using $0.8 \%$ agarose gel incubating $0.4 \mu \mathrm{g}$ pUC18 plasmid with each of the 4 extracts of Chromonephthea braziliensis with melatonin $(500 \mu \mathrm{M}) .1=$ dimethyl sulfoxide (DMSO); 2 = DMSO with melatonin; $3=200 \mu \mathrm{g} / \mathrm{mL} \mathrm{SnCl} ; 4=200 \mu \mathrm{g} / \mathrm{mL} \mathrm{SnCl}_{2}$ with melatonin; $5=250 \mu \mathrm{g} / \mathrm{mL}$ hexanic extract; 6 $=250 \mu \mathrm{g} / \mathrm{mL}$ dichloromethane extract; $7=250 \mu \mathrm{g} / \mathrm{mL}$ ethyl acetate extract; $8=250 \mu \mathrm{g} / \mathrm{mL}$ methanol extract. Significant statistical differences between negative control and tested concentrations under the same experimental conditions are identified by an asterisk $(\mathrm{P}<0.05)$. Form $\mathrm{I}=$ supercoiled native conformation; form $\mathrm{II}=$ open circle resulting from single-strand breaks; form $\mathrm{III}=$ linear resulting from double-strand breaks.

\section{Micronuclei in macrophages}

Table 5 shows the results obtained using the 4 extracts of $C$. braziliensis at final concentrations of $20,200,350$, and $500 \mu \mathrm{g} / \mathrm{mL}$. Although there is a dose-dependent increase there is no evidence of cytotoxicity being induced, as no significant differences were found between each group and its control.

Table 5. Micronucleus induction in macrophage assay using the 4 extracts of Chromonephthea braziliensis.

\begin{tabular}{|c|c|c|c|c|c|}
\hline Extract & C. braziliensis $(\mu \mathrm{g} / \mathrm{mL})$ & $\%$ M.I. \pm SD $^{\mathrm{a}}$ & $\%$ Apoptosis & $\%$ Necrosis & $\%$ Micronucleus \pm SD \\
\hline & DMSO & $3.7 \pm 0.7$ & 0.2 & 0.1 & $1.4 \pm 0.3$ \\
\hline \multirow{4}{*}{ n-Hex } & 20 & $2.8 \pm 0.4$ & 0.1 & 0.1 & $2.1 \pm 0.3$ \\
\hline & 200 & $3.1 \pm 0.7$ & 0.2 & 0.0 & $1.5 \pm 0.1$ \\
\hline & 350 & $2.2 \pm 1.3$ & 0.1 & 0.1 & $2.3 \pm 0.3$ \\
\hline & 500 & $2.4 \pm 0.8$ & 0.1 & 0.1 & $2.0 \pm 1.0$ \\
\hline \multirow{4}{*}{ DCM } & 20 & $1.7 \pm 0.7$ & 0.3 & 0.1 & $2.1 \pm 0.4$ \\
\hline & 200 & $2.2 \pm 0.1$ & 0.3 & 0.1 & $1.8 \pm 0.1$ \\
\hline & 350 & $4.8 \pm 1.3$ & 0.0 & 0.1 & $2.4 \pm 0.8$ \\
\hline & 500 & $2.3 \pm 0.3$ & 0.2 & 0.1 & $2.3 \pm 0.7$ \\
\hline \multirow[t]{4}{*}{ EtOAc } & 20 & $3.9 \pm 0.3$ & 0.1 & 0.0 & $2.5 \pm 1.0$ \\
\hline & 200 & $3.3 \pm 1.1$ & 0.1 & 0.0 & $1.3 \pm 0.1$ \\
\hline & 350 & $4.7 \pm 0.4$ & 0.3 & 0.1 & $1.7 \pm 0.8$ \\
\hline & 500 & $3.5 \pm 0.1$ & 0.2 & 0.1 & $1.8 \pm 1.0$ \\
\hline \multirow[t]{5}{*}{$\mathrm{MeOH}$} & 20 & $2.4 \pm 0.8$ & 0.2 & 0.2 & $1.9 \pm 0.8$ \\
\hline & 200 & $2.6 \pm 0.4$ & 0.1 & 0.1 & $1.3 \pm 0.3$ \\
\hline & 350 & $3.9 \pm 0.6$ & 0.3 & 0.1 & $1.6 \pm 0.1$ \\
\hline & 500 & $3.1 \pm 0.1$ & 0.2 & 0.1 & $1.8 \pm 0.3$ \\
\hline & MNNG & $2.5 \pm 0.6$ & 0.4 & 0.2 & $2.9 \pm 0.1^{*}$ \\
\hline
\end{tabular}

${ }^{a}$ Mitotic index per thousand. DMSO = dimethyl sulfoxide (negative control); MNNG $=0.5 \mu \mathrm{M}$ N-methyl-N-nitro-Nnitrosoguanidine (positive control). Significant statistical difference between the negative control and concentrations tested under the same experimental conditions is identified by an asterisk $(\mathrm{P}<0.05)$. For abbreviations, see Table 1. 


\section{Protein concentration and DPPH activity}

The protein concentration measured in each extract was $309 \mu \mathrm{g} / \mathrm{mL}$ for $\mathrm{n}-\mathrm{Hex} ; 492.5$ $\mu \mathrm{g} / \mathrm{mL}$ for DCM; $373 \mu \mathrm{g} / \mathrm{mL}$ for EtOAc; and only $69.1 \mu \mathrm{g} / \mathrm{mL}$ for MeOH. The decrease in the protein concentration observed in the extracts could be due to the sequential extraction.

The incubation of the extracts at different concentrations could suggest the ability of proteins to act as scavengers or form complexes with secondary metabolites, which would lead to decreases in antioxidant activity of the extracts. No significant differences $(P>0.05)$ were detected in the presence or absence of proteinase $\mathrm{K}(250 \mu \mathrm{g} / \mathrm{mL})$, suggesting that the proteins present in the extracts did not interfere with the antioxidant ability of the secondary metabolites (Figure 3).
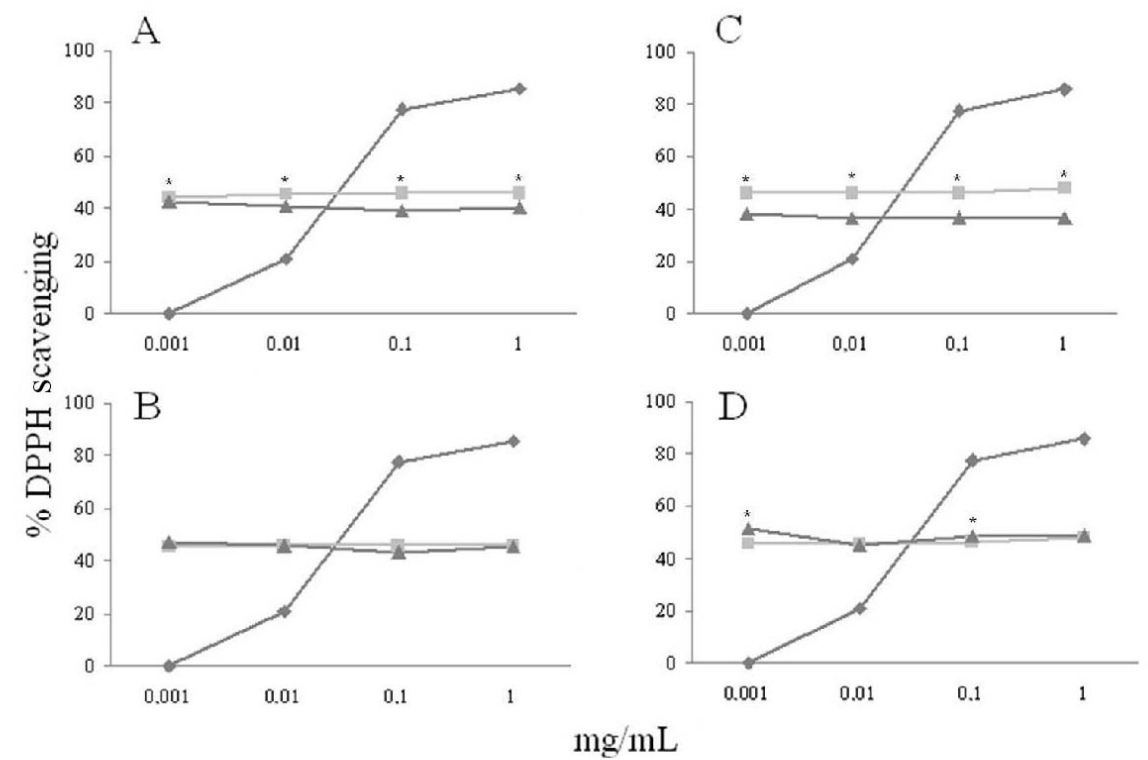

Percentage of DPPH scavenging in the absence of proteinase $\mathrm{K}$ Percentage of DPPH scavenging in the presence of proteinase $\mathrm{K}$

\section{A Proteinase $\mathrm{K}$}

Figure 3. Percentage of DPPH scavenging in the absence or in the presence of proteinase $\mathrm{K}(250 \mu \mathrm{g} / \mathrm{mL})$ at diferent concentrations $(0.001,0.01,0.1$, and $1 \mathrm{mg} / \mathrm{mL})$. A. Hexane extract; B. dichloromethane extract; C. ethyl acetate extract; D. methanol extract. Significant statistical differences between absence and presence of proteinase K under the same concentrations are identified by an asterisk $(\mathrm{P}<0.05)$.

In the Nephtheidae family, some species can be distinguished by their terpene distribution. Nephthea spp produce sesquiterpenes and/or diterpenes (70\% of cembranoid skeletons), Litophyton spp produce up to $100 \%$ cembranoid diterpenes, and Lemnalia, Paralemnalia, and Capnella spp produce 100\% sesquiterpenes (Coll, 1992). These secondary metabolites play various ecological roles for octocorals, namely in antipredation activity, and in the production of allelopathic agents, antifouling agents, and sex pheromones (Lages, 2003). 
Terpene activity in Sinularia spp (Alcyonacea), soft corals, has been described as having antipredation activity when in its colonial form, and dependent on inorganic compounds. Allelopathy is also a feature of the secondary metabolites and has been studied in parallel with antipredation activity. Soft corals have proved to be aggressive competitors in the race for space, leading to neighboring scleractinian coral mortality (Lages, 2003).

Terpenes can react with atmospheric ozone inducing hydrogen peroxide, a highly reactive oxygen species (Becker et al., 1990). In the same way, $\alpha$-pinene, a monoterpene, can cause oxidative damage (Singh et al., 2006). Assays for the antimutagenic and mutagenic activity of linalool, linalyl acetate, and $\beta$-caryophyllene - all terpenes - showed positive responses to mutagenicity for linalyl acetate and antimutagenic activity for linalool and $\beta$-caryophyllene (Di Sotto et al., 2008).

Different end points were evaluated in the present study. The negative mutagenicity and cytotoxicity responses were evaluated by Salmonella reverse assays, while genotoxicity was evaluated by micronucleus formation and DNA breakage. For the first assay, cells were incubated with the extracts. In the second one, there was direct interaction with the electrophilic compounds (plasmid DNA).

We only observed induced DNA breakage for DCM, EtOAc, and $\mathrm{MeOH}$ extracts. As these solvents have different polarities, the products extracted by them should in general be different. Quantitatively, $\mathrm{MeOH}$ extract presented greater DNA breakage than the others. This means that more polar substances in the extract present this potential. Recently, new composition of the monohydroxylated sterol fraction has been described: [22(E)-cholesta-5,22-dien-3 $\beta$-ol;

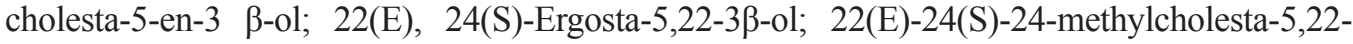

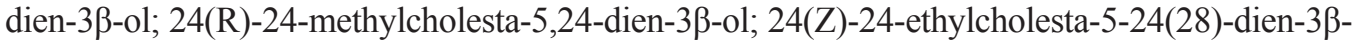

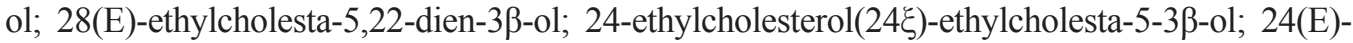
propylcholesta-5,24-dien-3 $\beta$-ol or 24(E)-isopropylcholesta-5,24-dien-3 $\beta$-ol]. A new hemiketal steroid, 23-keto-cladiellin-A, has also been isolated from the unpalatable hexane extract of $C$. braziliensis (Fleury et al., 2008). We now believe that the above mentioned products are not involved in DNA breakage.

Although macrophage micronucleus formation was not observed, the presence of DNA damage in free cell extracts (plasmid incubation) with the DCM, EtOAc, and $\mathrm{MeOH}$ extracts suggests that simple DNA breaks were induced. We suggest that among the secondary metabolites produced by the coral C. braziliensis, there is some substance, possibly a terpene or terpenoid, capable of generating oxidative stress that may be linked to some of its ecological interactions, enabling its continuation elsewhere.

\section{CONCLUSIONS}

The n-Hex, DCM, EtOAc, and MeOH extracts of $C$. braziliensis showed no cytotoxicity or mutagenicity, but genotoxicity was found for the DCM, EtOAc, and MeOH extracts. However, factors like the process of fractioning or test conditions to which these samples were subjected could have prevented their activation. Therefore, a methodology, which includes these questions, is needed for a more complete toxicological evaluation.

\section{ACKNOWLEDGMENTS}

Research supported by Fundação de Amparo à Pesquisa do Estado do Rio de Janeiro 
(FAPERJ), Conselho Nacional de Desenvolvimento Científico e Tecnológico (CNPq), Coordenação de Aperfeiçoamento de Pessoal de Nível Superior (CAPES, "Ciências do Mar" \#1137/2010), and Sub-Reitoria de Pós-Graduação e Pesquisa da Universidade do Estado do Rio de Janeiro (SR2-UERJ).

\section{REFERENCES}

Adey WH (2000). Coral reef ecosystems and human health: biodiversity counts! Ecosys. Health 6: 227-236.

Amarowicz R, Naczk M and Shahidi F (2000). Antioxidant activity of various fractions of non-tannin phenolics of canola hulls. J. Agric. Food Chem. 48: 2755-2759.

Bakkali F, Averbeck S, Averbeck D and Idaomar M (2008). Biological effects of essential oils - a review. Food Chem. Toxicol. 46: 446-475.

Becker KH, Brockmann KJ and Bechara J (1990). Production of hydrogen peroxide in forest air by reaction of ozone with terpenes. Nature 346: 256-258.

Burkhardt S, Reiter RJ, Tan DX, Hardeland R, et al. (2001). DNA oxidatively damaged by chromium(III) and H(2)O(2) is protected by the antioxidants melatonin, N(1)-acetyl-N(2)-formyl-5-methoxykynuramine, resveratrol and uric acid. Int. J. Biochem. Cell Biol. 33: 775-783.

Coll JC (1992). The chemistry and chemical ecology of octocorals (Coelenterata, Anthozoa, Octocorallia). Chem. Rev. 92: 613-631.

Di Sotto A, Evandri MG and Mazzanti G (2008). Antimutagenic and mutagenic activities of some terpenes in the bacterial reverse mutation assay. Mutat. Res. 653: 130-133.

Donia M and Hamann MT (2003). Marine natural products and their potential applications as anti-infective agents. Lancet Infect. Dis. 3: 338-348.

Eckl PM, Whitcomb WR, Michalopoulos G and Jirtle RL (1987). Effects of EGF and calcium on adult parenchymal hepatocyte proliferation. J. Cell Physiol. 132: 363-366.

Faulkner DJ (2000). Marine pharmacology. Antonie Van Leeuwenhoek 77: 135-145.

Felzenszwalb I, Pelielo de Mattos JC, Bernardo-Filho M and Caldeira-de-Araujo A (1998). Shark cartilage-containing preparation: protection against reactive oxygen species. Food Chem. Toxicol. 36: 1079-1084.

Ferreira CEL (2003). Non-indigenous corals at marginal sites. Coral Reefs. 22: 498.

Fleury BG, Lages BG, Barbosa JP, Kaiser CR, et al. (2008). New hemiketal steroid from the introduced soft coral Chromonephthea braziliensis is a chemical defense against predatory fishes. J. Chem. Ecol 34: 987-993.

Gomes EM, Souto PR and Felzenszwalb I (1996). Shark-cartilage containing preparation protects cells against hydrogen peroxide induced damage and mutagenesis. Mutat. Res. 367: 204-208.

Karbownik M and Reiter RJ (2000). Antioxidative effects of melatonin in protection against cellular damage caused by ionizing radiation. Proc. Soc. Exp. Biol. Med. 225: 9-22.

Lages BG (2003). Avaliação do Potencial Invasor do Coral Alcionáceo Stereonephthya aff. curvata (Nephtheidae Alcyonacea) na Reserva Extrativista Marinha de Arraial do Cabo (RJ). Master's thesis, UFF, Rio de Janeiro.

Lages BG, Fleury BG, Ferreira CEL and Pereira RC (2006). Chemical defense of an exotic coral as invasion strategy. $J$. Exp. Mar. Biol. Ecol. 328: 127-135.

Levin DE, Hollstein M, Christman MF, Schwiers EA, et al. (1982). A new Salmonella tester strain (TA102) with A X T base pairs at the site of mutation detects oxidative mutagens. Proc. Natl. Acad. Sci. U. S. A. 79: 7445-7449.

Maron DM and Ames BN (1983). Revised methods for the Salmonella mutagenicity test. Mutat. Res. 113: 173-215.

Maróstica Júnior MR (2008). Biotransformação de Terpenos para a Produção de Compostos de Aroma e Funcionais. Doctoral thesis, Faculdade de Engenharia de Alimentos, UNICAMP, Campinas.

Oliveira AES and Medeiros MS (2008). What we must do - An exotic invasive species in paradise. Biotemas 21: 149-151.

Onuki J, Almeida EA, Medeiros MH and Di Mascio P (2005). Inhibition of 5-aminolevulinic acid-induced DNA damage by melatonin, N1-acetyl-N2-formyl-5-methoxykynuramine, quercetin or resveratrol. J. Pineal Res. 38: 107-115.

Pawlik JR (1993). Marine invertebrate chemical defenses. Chem. Rev. 93: 1911-1922.

Reiter RJ, Melchiorri D, Sewerynek E, Poeggeler B, et al. (1995). A review of the evidence supporting melatonin's role as an antioxidant. J. Pineal Res. 18: 1-11.

Reiter RJ, Tan DX, Manchester LC and Qi W (2001). Biochemical reactivity of melatonin with reactive oxygen and nitrogen species: a review of the evidence. Cell Biochem. Biophys. 34: 237-256.

Sammarco PW and Coll JC (1992). Chemical adaptations in the Octocorallia: evolutionary considerations. Mar. Ecol. Prog. Ser. 88: 93-104. 
Singh HP, Batish DR, Kaur S, Arora K, et al. (2006). $\alpha$-Pinene inhibits growth and induces oxidative stress in roots. Ann. Bot. 98: 1261-1269.

Sipkema D, Franssen MC, Osinga R, Tramper J, et al. (2005). Marine sponges as pharmacy. Mar. Biotechnol. 7: 142-162. Stankevicins L, Aiub C, Maria LC, Lobo-Hajdu G, et al. (2008). Genotoxic and antigenotoxic evaluation of extracts from Arenosclera brasiliensis, a Brazilian marine sponge. Toxicol. In Vitro 22: 1869-1877.

WHO (2002). Hazard Assessment - Part 3: Dose-Response Assessment. In: Guidelines for Assessing Human Health Risks from Environmental Hazards. Environmental Health Risk Assessment. World Health Organization. 